\title{
MEDIA DAN PERSPEKTIF FEMINIS
}

\author{
Nahdatunnisa Asry \\ Jurusan Dakwah, Komunikasi dan Ushuluddin IAIN Bone \\ nahdatunnisa.asry@gmail.com
}

\begin{abstract}
Abstrak
Selama masa ini perempuan adalah objek utama media. Diskusi utama untuk feminis adalah kesetaraan antara pria dan wanita. Pengamat isu-isu perempuan dan media harus bergandengan tangan untuk bersama-sama melahirkan pembaca yang sehat tanpa diisi dengan pendapat dan asumsi negatif tetapi melihat masalahnya secara seimbang. Di sisi lain wanita harus bisa mempertahankan cara hidup yang sesuai dengan norma. pentingnya kerjasama yang baik antara pengamat isu-isu perempuan dan media diperlukan, pemantauan media yang sering memuat berita yang cenderung diskriminatif dan stereotip perempuan perlu dilakukan. Selain itu, transfer pengetahuan ke media secara individual merupakan masalah kesetaraan untuk melahirkan jurnalisme perspektif perempuan.
\end{abstract}

Kata kunci: Media, Feminisme

\begin{abstract}
During this time women were the main objects of the media. The main discussion for feminists is the equality between men and women. Observer of women's issues and the media must join hands to jointly give birth to healthy readers without being filled with negative opinions and assumptions but seeing the problem in a balanced manner. On the other hand women must be able to maintain a way of life that is in accordance with the norm. the importance of good cooperation between observers of women's issues and the media is necessary, monitoring the media that often contains news that tends to be discriminatory and stereotypes of women needs to be done. In addition, the transfer of knowledge to the media individually is primarily an issue of equality to give birth to women's perspective journalism.
\end{abstract}

Keyword: Media, Feminism 


\section{PENDAHULUAN}

Feminisme (tokohnya disebut Feminis) adalah sebuah gerakan perempuan yang menuntut emansipasi atau kesamaan dan keadilan hak dengan pria. Feminisme sebagai filsafat dan gerakan berkaitan dengan Era Pencerahan di Eropa yang dipelopori oleh Lady Mary Wortley Montagu dan Marquis de Condorcet. Setelah Revolusi Amerika 1776 dan Revolusi Prancis pada 1792 berkembang pemikiran bahwa posisi perempuan kurang beruntung daripada lakilaki dalam realitas sosialnya Ketika itu, perempuan, baik dari kalangan atas, menengah ataupun bawah, tidak memiliki hak-hak seperti hak untuk mendapatkan pendidikan, berpolitik, hak atas milik dan pekerjaan. Oleh karena itulah, kedudukan perempuan tidaklah sama dengan laki-laki dihadapan hukum. Pada 1785 perkumpulan masyarakat ilmiah untuk perempuan pertama kali didirikan di Middelburg, sebuah kota di selatan Belanda. ${ }^{1}$

Pembahasan utama bagi kaum feminis adalah persamaan antara laki-laki dan perempuan. Hal ini termuat pula dalam Al-Qur'an. Studi yang dilakukan oleh Nasaruddin Umar terhadap Al-Qur'an menunjukkan adanya kesetaraan gender. Nasaruddin menemukan lima variabel yang mendukung yakni:

1. Laki-laki dan perempuan sama sebagai hamba. Hal ini bisa dilihat dalam Q.S. Al-Hujarat (49:13) dan An-Nahl (16:97)

2. Laki-laki dan perempuan sebagai khalifah di bumi. Hal ini ditunjukkan dengan Q.S. Al-Baqarah (2:30) dan Al-An'am (6:165)

3. Laki-laki dan perempuan menerima perjanian primordial. Hal ini bisa dilihat dalam Q.S. Al-A'raf $(7: 172,4)$

4. Adam dan Hawa terlibat secara aktif dalam drama kosmis. Kejalasan ini terlihat dalam Q.S. Al-Baqarah (2:35 dan 187), Al-A'raf (7:20, 22, 23, 5)

5. Laki=laki dan perempuan berpotensi meraih prestasi

${ }^{1}$ http://id.wikipedia.org/wiki/Feminisme, diakses 29 Januari pukul 22.45 wib. 
Hal ini seperti yang terlihat dalam Q.S. Ali=Imran (3:195), An-Nisa (4:24), An-Nahl (16:197), dan Al-Mu'min (40:40). ${ }^{2}$

Demikian pembahasan terkait feminisme dalam Al-Qur'an. Selanjutnya, beralih pada kajian media berdasarkan perspektif feminis. Menurut teori feminisme, media dan masyarakat tertarik kepada bagaimana media mengonstruksi pandangan-pan dangan tentang perempuan. ${ }^{3}$ Pandangan ini melihat banyaknya kesenjangan antara kaum laki-laki dan perempuan, seperti objektifikasi perempuan, proporsi perempuan dalam organisasi media serta perempuan dalam pemberitaan media.

Selama ini perempuan adalah obyek utama dari media, hal ini dapat diamati dari iklan-iklan produk-produk kecantikan maupun acara lain yang mengetengahkan perempuan sebagai obyeknya. Tidak ada yang salah dengan media, namun bagaimana peran media dalam mengedukasi masyarakat adalah suatu hal yang patut dicermati. Malalui medialah masyarakat mengetahui banyak informasi. Membahas menganai perempuan, bisa dilihat fenomena saat ini ketika perempuan banyak termakan oleh iklan-iklan kecantikan yang banyak membuat kaum hawa justru ingin meniru orang lain (merubah kondisi fisik misalnya ingin terlihat lebih putih dan lainnya).

Ketika terjadi kasus tindak pidana yang melibatkan perempuan misalanya, terkadang yang dibahas bukanlah kasusnya secara lebih detail, namun terkadang lebih menonjolkan sisi keperempuannya misalnya lebih dibahas mengenai tersangkanya yang merupakan perempuan yang cantik, seksi ataupun mengenai pakaian yang sedang digunakan. Hal ini yang terkadang diekspose oleh media dari

\footnotetext{
${ }^{2}$ Nasaruddin Umar. Argumen Kesetaraan Jender Perspektif Al-Qur'an (Jakarta: Paramadina, 2001), h. 247.

${ }^{3}$ http://www.isi-dps.ac.id/berita/televisi-sebagai-konstruksi-realitas-bagian-i diakses 29 Januari 2013 pukul 09.57 wib.
} 
seorang perempuan yang justru menutupi masalah-masalah krusial yang seharusnya lebih dapat dijadikan edukasi bagi masyarakat. ${ }^{4}$

Rach Alia dari Aliansi Jurnalis Independen (AJI), telah melakukan penelitian tentang bagaimana perempuan digambarkan di sejumlah media nasional (Indo Pos, Kompas, Warta Kota, Republika, Suara Pembaruan, Koran Tempo dan Media Indonesia) periode Juli-Agustus 2010. Hasil penelitian tersebut ditemukan masih banyak berita dengan kategori kekerasan terhadap perempuan yang mendominasi berita dalam 7 koran tersebut.

Sementara pemberitaan mengenai kiprah perempuan masih kurang. Penggunakaan bahasa juga menjadi perhatian dalam penelitian itu, karena misalnya pemberitaan kasus-kasus permerkosaan, atau korupsi yang dituduhkan kepada perempuan cenderung menggunakan pelabelan pada korban atau pelaku (yang notabenenya seorang perempuan). Sehingga menciptakan stigma dan praduga di masyarakat.

Dengan lahirnya stigma "miring" terhadap perempuan secara langsung maupun tidak berdampak pada aktivitas perempuan di ruang publik, sehin gga lahirlah kebijakan-kebijakan berbasis agama yang membatasi ruang gerak perempuan di tengah-tengah masyarakat. Dampaknya ketika terjadi kejahatan terhadap perempuan baik sebagai korban maupun pelaku ada kecenderungan yang melahirkan stigmatisasi dan pengecapan bahwa perempuan itu bukan orang "baikbaik". Semua itu tidak bisa dilepaskan karena kurangnya kesadaran gender dari para penulis berita maupun pengambil kebijakan di media dan juga kurang pemahaman dan pengawasan pelaksanaan kode etik jurnalistik itu sendiri.. 5

wib

${ }^{4}$ http://psg.uii.ac.id/index.php/RADIO/Amin.html diakses 29 Januari 2013 pukul 22.34

${ }^{5} \mathrm{http}$ ://www.rahima.or.id/index.php?option= com_content $\&$ view $=$ article $\&$ id $=858$ : bagaimana -media-memotret-perempuan- \&catid =1:berita\&Itemid=18 diakses 29 Januari pukul 22.53 wib. 


\section{HASI DAN PEMBAHASAN}

\section{A. Sejarah dan Aliran Feminisme}

Kata feminisme dicetuskan pertama kali oleh aktivis sosialis utopis, Charles Fourier pada tahun 1837. Pergerakan yang berpusat di Eropa ini berpindah ke Amerika dan berkembang pesat sejak publikasi John Stuart Mill, "Perempuan sebagai Subyek" (The Subjection of Women) pada tahun (1869). Perjuangan mereka menandai kelahiran feminisme Gelombang Pertama.

Pada awalnya gerakan ditujukan untuk mengakhiri masa-masa pemasungan terhadap kebebasan perempuan. Secara umum kaum perempuan (feminin) merasa dirugikan dalam semua bidang dan dinomorduakan oleh kaum laki-laki (maskulin) dalam bidang sosial, pekerjaan, pendidikan, dan politik khususnya - terutama dalam masyarakat yang bersifat patriarki. Dalam masyarakat tradisional yang berorientasi Agraris, kaum laki-laki cenderung ditempatkan di depan, di luar rumah, sementara kaum perempuan di dalam rumah. Situasi ini mulai mengalami perubahan ketika datangnya era Liberalisme di Eropa dan terjadinya Revolusi Perancis di abad ke-XVIII yang merambah ke Amerika Serikat dan ke seluruh dunia.

Pergerakan di Eropa untuk "menaikkan derajat kaum perempuan" disusul oleh Amerika Serikat saat terjadi revolusi sosial dan politik. Pada tahun 1792 Mary Wollstonecraft membuat karya tulis berjudul "Mempertahankan Hak-hak Wanita" (Vindication of the Right of Woman) yang berisi prinsip-prinsip feminisme dasar yang digunakan dikemudian hari. Pada tahun-tahun 1830-1840 sejalan terhadap pemberantasan praktik perbudakan, hak-hak kaum prempuan mulai diperhatikan dengan adanya perbaikan dalam jam kerja dan gaji perempuan, diberi kesempatan ikut dalam pendidikan, serta hak pilih. Menjelang abad 19 feminisme lahir menjadi gerakan yang cukup mendapatkan perhatian dari para perempuan kulit putih di Eropa. Perempuan di negara-negara penjajah Eropa 
memperjuangkan apa yang mereka sebut sebagai keterikatan (perempuan) universal (universal sisterhood). ${ }^{6}$

Gerakan yang bertujuan agar wanita mandiri, tak bergantung pada pria dan memberontak pada dominasi pria juga terjadi di Amerika Serikat. Gerakan ini disebut Women's Lib yang dimulai sejak 1960-an. ${ }^{7}$ Sedangkan di Indonesia dikenal nama R.A Kartini sebagai pahlawan yang memperjuangkan emansipasi wanita.

Seiring dengan perkembangan gerakan ini maka akhirnya feminisme dapat dikelompokkan dalam beberapa aliran ${ }^{8}$, diantaranya sebagai berikut:

\section{a. Feminisme Liberal}

Apa yang disebut sebagai Feminisme Liberal ialah terdapat pandangan untuk menempatkan perempuan yang memiliki kebebasan secara penuh dan individual. Aliran ini menyatakan bahwa kebebasan dan kesamaan berakar pada rasionalitas dan pemisahan antara dunia privat dan publik. Setiap manusia demikian menurut mereka- punya kapasitas untuk berpikir dan bertindak secara rasional, begitu pula pada perempuan. Akar ketertindasan dan keterbelakangan pada perempuan ialah karena disebabkan oleh kesalahan perempuan itu sendiri. Perempuan harus mempersiapkan diri agar mereka bisa bersaing di dunia dalam kerangka "persaingan bebas" dan punya kedudukan setara dengan lelaki.

\section{b. Feminisme Marxis}

Aliran ini memandang masalah perempuan dalam kerangka kritik kapitalisme. Asumsinya sumber penindasan perempuan berasal dari eksploitasi kelas dan cara produksi. Teori Friedrich Engels dikembangkan menjadi landasan aliran ini-status perempuan jatuh karena adanya konsep kekayaaan pribadi

\footnotetext{
${ }^{6} \mathrm{http}$ ///id.wikipedia.org/wiki/Feminisme, diakses 29 Januari pukul 22.45 wib.

${ }^{7}$ Deddy Mulyana, Komunikasi Lintas Budaya: Pemikiran, Perjalanan dan Khayalan (Bandung: PT. Remaja Rosdakarya, 2011), h. 44.

${ }^{8} \mathrm{http} / / /$ id.wikipedia.org/wiki/Feminisme, diakses 29 Januari pukul 22.45 wib.
} 
(private property). Kegiatan produksi yang semula bertujuan untuk memenuhi kebutuhan sendri berubah menjadi keperluan pertukaran (exchange). Laki-laki mengontrol produksi untuk exchange dan sebagai konsekuensinya mereka mendominasi hubungan sosial. Sedangkan perempuan direduksi menjadi bagian dari property. Sistem produksi yang berorientasi pada keuntungan mengakibatkan terbentuknya kelas dalam masyarakat—borjuis dan proletar. Jika kapitalisme tumbang maka struktur masyarakat dapat diperbaiki dan penindasan terhadap perempuan dihapus.

\section{c. Feminisme sosialis}

Sebuah faham yang berpendapat "Tak Ada Sosialisme tanpa Pembebasan Perempuan. Tak Ada Pembebasan Perempuan tanpa Sosialisme". Feminisme sosialis berjuang untuk menghapuskan sistem pemilikan. Lembaga perkawinan yang melegalisir pemilikan pria atas harta dan pemilikan suami atas istri dihapuskan seperti ide Marx yang menginginkan suatu masyarakat tanpa kelas, tanpa pembedaan gender.

Feminisme sosialis muncul sebagai kritik terhadap feminisme Marxis. Aliran ini hendak mengatakan bahwa patriarki sudah muncul sebelum kapitalisme dan tetap tidak akan berubah jika kapitalisme runtuh. Kritik kapitalisme harus disertai dengan kritik dominasi atas perempuan. Feminisme sosialis menggunakan analisis kelas dan gender untuk memahami penindasan perempuan. Ia sepaham dengan feminisme marxis bahwa kapitalisme merupakan sumber penindasan perempuan. Akan tetapi, aliran feminis sosialis ini juga setuju dengan feminisme radikal yang menganggap patriarkilah sumber penindasan itu. Kapitalisme dan patriarki adalah dua kekuatan yang saling mendukung. Seperti dicontohkan oleh Nancy Fraser di Amerika Serikat keluarga inti dikepalai oleh laki-laki dan ekonomi resmi dikepalai oleh negara karena peran warga negara dan pekerja adalah peran maskulin, sedangkan peran sebagai konsumen dan pengasuh anak adalah peran feminin. Agenda perjuangan untuk memeranginya adalah menghapuskan kapitalisme dan sistem patriarki. Dalam konteks Indonesia, 
analisis ini bermanfaat untuk melihat problem-problem kemiskinan yang menjadi beban perempuan.

\section{B. Media dari Perspektif Feminis}

\section{Perempuan Sebagai Objektifikasi Media}

Sejak awalnya kegiatan jurnalistik baik cetak maupun elektronik selalu didominasi pria. Beberapa pakar menyebut jurnalistik ini sebgai jurnailistik maskulin yang menggunakan pandangan dan subjektivitas pria untuk meneropong wanita. Pantaslah bila sampul majalah-majalah umum, sering dihiasi dengan gambar wanita. Banyak produk atau jasa yang diiklankan seperti, motor, mobil, dan celana jins dalam majalah dan surat kabar juga dihiasai dengan sosok wanita cantik yang berpenampilan minim. Nilai mereka direduksi menjadi sebatas makhluk biologis semata. Menurut perkiraan, 90 persen periklanan memanfaatkan wanita sebagai model iklannya. ${ }^{9}$

Para penulis feminis secara kritis menganalisis media yang menayangkan tubuh perempuan dalam masyarakat Barat patriarki. Sebuah sisi penting argument feminis adalah bahwa media telah berperan dalam objektifikasi tubuh kaum wanita; tubuh wanita dalam pertunjukan; kaum wanita wajib menjadikan tubuh mereka sebagai pertunjukan yang memadai dan diterima; sebagai objek yang eksternal bagi mereka. Beberapa penulis mengalihkan perhatian mereka kepada tubuh perempuan yang lebih kurus yang digambarkan media, yang mencerminkan perubahan pada persepsi tentang bobot ideal biomedis bagi kaum wanita. Standar demikian telah telah diinterpretasikan sebagai mencerminkan penindasan atas kaum wanita yang menonjolkan citra cultural yang tidak realistik tentang kecantikan.

${ }^{9}$ Deddy Mulyana, Komunikasi Massa (Bandung: Widya Padjajaran,2008), h. 81. 
Lebih jauh banyak feminis yang menganut pendapat mengenai adanya hubungan antara citra media tentang tubuh perempuan yang langsing dan perkembangan kebiasaan buruk makan seperti anoreksia nervosa. ${ }^{10}$

Saat ini ketika karya-karya seni kreatif seperti iklan menjadi konsumsi masyarakat dalam berbagai media massa, posisi perempuan ini menjadi sangat potensial untuk dikomersialkan dan dieksploitasi, karena posisi perempuan menjadi sumber inspirasi dan juga tambang uang yang tak habis-habisnya. Permasalahan seperti ini bukan saja terjadi di Indonesia, melainkan juga di negara lain. Bahkan juga di negara-negara Barat yang banyak dihuni para feminis bersuara lantang. Ini kareena iklan, bagaimanapun adalah sebuah produk industri yang berwajah kapitalis. Dan kapitalisme, mana peduli dengan isu kesetaraan gender. ${ }^{11}$

Eksploitasi peremuan dalam pencitraan media massa tidak saja karena kerelaan perempuan, namun juga karena kebutuhan kelas sosial itu sendiri, sehingga mau ataupun tidak kehadiran perempun menjadi sebuah kebutuhan dalam kelas sosial tersebut. Sayangya kehadiran perempuan dalam kelas sosial itu, masih menjadi bagian dari refleksi realitas sosial masyarakatnya, bahwa perempuan selalu menjadi subordinat kebudayaan laki-laki. ${ }^{12}$

Fakta ini muncul sebagai sebuah ketidakadilan yang menerpa kaum perempuan. Lambat laun fenomena ini akan menjadi sebuah pembodohan ketika semua perempuan berpendapat bahwa gambar apapun yang Anda lihat melalui media pada dasarnya memberi pesan kepada Anda bahwa seharusnya Anda terlihat seperti itu (Alison Shaw, 2007: 317). Keadaan ini dapat pula dikategorikan sebagai aplikasi teori agenda setting. Dimana media dapat

10 Alison Shaw, Metode Penelitian Komunikasi: Contoh-Contoh Penelitian Kualitatif Dengan Pendekatan Praktis (Bandung. PT. Remaja Rosdakarya, 2007), h.311.

${ }^{11}$ Santi Indra Astuti, Representasi Perempuan Indonesia dalam Komuniksi Visual: Wacana yang (Belum) Berubah. (Jurnal Komunikasi Mediator Volume 5 Nomor 2, 2004), h. 316.

${ }^{12}$ Burhan Bungin, Sosiologi Komunikasi (Jakarta: Kencana, 2006) h.342. 
menentukan content apa saja yang akan disajikan kepada audience wanita sebagai penonton televisi terbanyak dan "merayu" nya untuk menjadi konsumen atas semua iklan yang ditayangkan.

Seksploitation merupakan sebutan dari kaum feminis yang menunjukkan betapa tidak adilnya kalangan media karena mengeksploitasi perempuan dengan menginjak-nginjak martabatnya, demi menaikkan tiras surat kabar atau majalah. Dalam hal ini sangat jelas bahwa perempuan dieksploitasi untuk kepentingan komersil. Kalangan media cetak selalu membela diri, dengan menyatakan bahwa pembaca mau membacanya, dan kalangan perempuan sendiri senang pula membaca berita-berita tentang kaumnya.

Perempuan sebagai objek media massa merupakan kenyataan ketidakadilan gender yang dialami perempuan dalam masyarakat. Akar ketidakadilan gender berkaitan dengan budaya patriarki, sebagaimana pemahaman feminisme sosialis. Dalam hal ini terlihat jelas bahwa laki-laki menjadi subjek dengan kekuatannya, dan perempuan sebagai objek yang lemah dan dipojokkan. ${ }^{13}$ Para penganut feminis sangat keberatan dengan hal ini. Namun inilah yang terjadi dan mayoritas kaum perempuan entah sadar atau tidak turut dalam arus pemikiran tersebut. Mereka seolah-olah tunduk pada doktrin media.

\section{Proporsi Perempuan Dalam Organisasi Media}

Selain sebagai objek atau "sasaran empuk" pelaku media terutama iklan yang menjadikan perempuan sebagai tokoh utama, ketidakadilan juga muncul pada struktur organisasi media. Ada ketidaksamaan frekuensi atas porsi kehadiran perempuan dalam organisasi media. Di televisi, contohnya lebih banyak menghadirkan peran laki-laki daripada perempuan dan laki laki dimunculkan lebih sering sebagai peran pemimpin (Fejes, 1992). Hanya 12 persen dari penyebaran video MTV pada 1984 satu perempuan sebagai pemimpin (Brown and Campbell, 1986).

\footnotetext{
${ }^{13}$ http://ekawenats.blogspot.com/2006_03_19_archive.html diakses 29 Januari 2013 pukul 22.30 wib
} 
Kontrol atas ciptaan dan penghasilan dari citra media juga hanya sampai peran laki-laki. Pertimbangkan media massa. Pada awal 1990 hanya sepertiga saja dari kekuatan kerja jurnalistik diisi oleh wanita. Bagaimanapun level atas dari media perusahaan utama organisasi adalah hampir seluruhnya laki-laki. Sebagai tambahan, wanita menduduki hanyalah 25 persen manajemen tengah dan 6 persen manajemen koran pada posisi teratas. Pada 1994, perempuan menduduki posisi direktur dari surat kabar hanya pada 20,6 persen. Pada 1995, penulis perempuan hanyalah 19 persen untuk cerita halaman depan di koran dan koresponden perempuan hanyalah 20. Penunjukan Hollywood, antara lain menurut sejarah adalah jarang perempuan sebagai direktur. ${ }^{14}$

Seperti juga jumlah karyawan pria yang yang mengelola penerbitan surat kabar atau majalah, jumlah karyawan pria yang mengelola siaran televisi jauh lebih banyak daripada karyawan wanitanya. Bahkan bila terdapat karyawan wanita mereka tidak memegang posisi-posisi kunci yang menentukan kebijakan penerbitan atau penyiaran. Padahal jumlah wanita di seluruh dunia juga di Indonesia, konon lebih besar daripada jumlah pria. ${ }^{15}$

Hadirnya seorang perempuan di belakang televisi, masuk dalam proses produksi diharapkan mampu berperanan dan mewarnai penokohan dan kesetaraan perempuan dalam media televisi. Bahkan tidak sekedar memaknai tuntutan emansipasi dan kesetaraan gender belaka, namun juga sikapnya sebagai seorang feminis. ${ }^{16}$

Apabila ditelusuri maka kekuasaan menjadi unsur yang menghubungkan setiap pemikiran feminis tersebut. Utamanya pada pemikiran feminisme marxis yamg menggap dominasi kekuasaan laki-laki yang menjadi sumber ketidakadilan.

\footnotetext{
${ }^{14}$ David Croteau dan William Hoynes, Media/Society: Industries, Images, And Audiences
} (California: Pine Forge Press, 1997) h. 147-148.

${ }^{15}$ Deddy Mulyana, Komunikasi Massa (Bandung: Widya Padjajaran,2008), h. 81.

${ }^{16}$ Priyo Soemandoyo, Wacana Gender \& Layar Televisi: Studi Perempuan dalam Pemberitaan Televisi Swasta (Yogyakarta: LP3y dan Ford Foundation, 1999), h.160. 
Kekuasaan dapat menghubungkan dominasi dan subordinasi, dapat juga menjadi sumber, dan juga dapat menjadi pemberdayaan atau transformasi. Feminis mempelajari cara kekuasaan digunakan oleh pria untuk mendominasi wanita dan cara wanita menggunakan kekuasaannya untuk mendominasi wanita lain berdasarkan usia, kelas, ras, dan sebagainya. Jika dilihat dari teori komunikasi sender-reciever model, feminsime dapat menjelaskan hubungan kekuasaan yang ada.

Sehingga teori komunikasi feminis menganggap jika seseorang yang berada di pusat komunikasi memiliki kekuasaan terhadap massa, maka dia mempunyai andil dalam memutuskan apakah informasi akan dikirimkan seutuhnya atau tidak oleh sender kepada receiver. Seperti dalam struktur newsroom tradisional dimana konten dikategorikan berdasarkan genre konten yang ditulis masyarakat, politi, kesehatan, olahraga, dan sebagainya. Teori feminis beranggapan bahwa batasan yang ada harusnya lebih cair yang memungkinkan banyaknya suara partisipan dan pengalaman yang terlibat sehingga semakin banyak pilihan yang ada. ${ }^{17}$

Semua aliran feminisme menuntut adanya kesederajatan antara laki-laki dan perempuan. Termasuk dalam hal pekerjaan. Feminis marxisme melihat adanya dominasi kontrol produksi oleh laki-laki sehingga dianggap tidak adil oleh mereka. Sedangkan Feminis liberal menganggap bahwa perempuan dan laki-laki, sebagai makhluk rasional, pada dasarnya sama, meskipun penampilan luar mereka berbeda dan karena itu struktur hierarkis bahwa pria terpisah dan perempuan berdasarkan sifat fisik mereka harus diganti dengan meritokrasi yang adil dan setara.

\section{Perempuan Dalam Pemberitaan Media}

${ }^{17}$ http ://konvergensi.komunikasi. or. Id / 18 /post /2012 /10/konvergensi - media dalam - perspektif - feminisme. html diakses 29 Januari 23.00 wib 
Secara global struktur muatan pemberitaan media massa pada umumnya belum secara seimbang merespons kepentingan perempuan. Pemberitaan media massa umumnya memberitakan ruang publik laki-laki. Mulai persoalan negara, politik, militer, olahraga, pemerintahan lokal, sampai dengan berbagai wacana publik laki-laki lainnya. Namun ketika ada pemberitaan masalah perempuan, sorotan menjadi domestik, seperti keterampilan rumah tangga, pengasuhan anak, kosmetika dan kecantikan, terkecuali ketika ada tokoh publik perempuan, baru kemudian menjadi berita utama, itupun terkesan tidak menjadi agenda setting media pada hari itu, karena berita utama tersebut tidak diikuti oleh pemberitan atau tulisan-tulisan lain di bagian lain pemberitaan hari itu. ${ }^{18}$

Pemberitaan tentang perempuan di media massa masih menonjolkan peran perempuan di ranah domestik daripada ranah publik. Selain itu, citra perempuan yang ditampilkan oleh media massa pun masih klise, dimana peran perempuan sebagai ibu dan istri saja. Sehingga melahirkan kostruksi sosial secara tidak langsung bahwa perempuan tidak mungkin melakukan kejahatan atau melanggar norma yang berlaku.

Padahal Deklarasi Beijing menyebutkan bahwa gambaran perempuan di media harus seimbang dan tidak klise. Tetapi media di negara kita menampilan citra perempuan sebagian besar cenderung stereotip, bahkan masih diskriminatif, sangat jarang kita menemukan tulisan yang mengeksplorasi kiprah perempuan secara seimbang. ${ }^{19}$

\section{Problem Solving}

Gender merupakan pelabelan yang pada kenyataannya bisa dipertukarkan antara laki-laki dan perempuan. Perbedaan gender sesungguhnya tidak menjadi masalah apabila tidak ada pemberitaan yang menjadikan perempuan sebagai objek

\footnotetext{
${ }^{18}$ Burhan Bungin, Sosiologi Komunikasi (Jakarta: Kencana, 2006) h.344.

${ }^{19} \mathrm{http}: / /$ www.rahima.or.id/index.php?option= com_content $\&$ view $=$ article\&id=858: bagaimana-media-memotret-perempuan- \&catid= 1:berita\&Itemid= 18 diakses 29 Januari pukul
} 22.53 wib. 
yang dieksploitasi. Menurut salah satu wartawan, Ana Nadhya Abrar, Indonesia lebih memiliki sensitifities gender dalam memahami masalah yang dihadapi perempuan. Citra perempuan dalam pandangan pers Indonesia masih rendah, karena kebijakan keredaksian yang ternyata terkalahkan oleh kebijakan pemasaran yaitu segmentasi, konstribusi iklan dan keinginan pembaca. ${ }^{20}$

Kondisi ini juga menjadi salah satu kasus yang dihadapi kaum feminis dan tentu saja ditentang. Selalu ada ketidakadilan dalam memperlakukan perempuan. Mestinya pemberitaan tersebut bisa lebih berimbang dengan memberikan porsi yang sesuai tanpa melihat jenis kelamin tokoh yang diberitakan.

Meskipun Indonesia sudah memiliki Komisi Penyiaran Nasional, namun disisi lain masyarakat juga harus lebih pintar membentuk jati diri sebagai proteksi dari dalam. Jangan mudah tergiur oleh informasi yang diperoleh, lebih bijak dalam mengkonsumsi isi media, serta sebaiknya menggunakan apa yang cocok dan pas untuk digunakan.

\section{PENUTUP}

Peran media yang selama ini secara lebih luas mampu memberikan pelajaran bagi masyarakat harus lebih memainkan perannya guna memberi pemberitaan yang berimbang dan memberi contoh yang lebih baik bagi masyarakat. Pemerhati isu perempuan dan media harus bergandengan tangan untuk bersama-sama melahirkan pembaca yang sehat tanpa dipenuhi opini dan asumsi negatif tetapi melihat permasalahan secara seimbang

Di sisi lain kaum perempuan harus mampu mempertahankan cara hidup yang sesuai dengan norma. Karena bagaimana mungin seorang perempuan akan memperoleh penghargaan dari kaum lelaki jika dia sendiri tidak menghormati dan menghargai dirinya sendiri, seperti cara berpakaian di depan umum. Banyak di

\footnotetext{
${ }^{20}$ http://ekawenats.blogspot.com/2006_03_19_archive.html diakses 29 Januari 2013 pukul $22.30 \mathrm{wib}$
} 
antara mereka yang berpakaian minim dan seksi dengan alasan mengikuti perkembangan mode. Namun kebiasaan semacam ini jelas akan mengundang tindakan negatif.

Jika mereka mampu berperilaku dan berpenampilan yang seuai dengan norma yang berlaku, insya Allah pelecehan dan kekerasan seksual yang saat ini banyak menimpa kaum perempuan dapat dihindarkan, karena pada dasarnya kejahatan dan pelecehan seksual banyak terjadi sebagai akibat dari penampilan si korbannya itu sendiri. Selain itu melalui penghargaan terhadap diri sendiri oleh kaum perempuan diharapkan posisi perempuan yang selalu menjadi objek dalam berbagai kegiatan kaum lelaki dan dunia usaha dapat dihindarkan dan penghargaan yang layak dapat diterima oleh kaum perempuan sesuai dengan prestasi bukan rasa iba atau karena pengorbanan harga diri.

Selain itu diperlukan pentingnya kerjasama yang baik antara pemerhati isu perempuan dengan media, melakukan monitoring terhadap media yang kerap memuat berita yang cenderung diskriminatif dan stereotype terhadap perempuan perlu dilakukan. Selain itu transfer pengetahuan ke media secara perorangan terutama isu kesetaraan guna melahirkan jurnalisme berspektif perempuan juga menjadi penting.

\section{DAFTAR PUSTAKA}

\section{Buku}

Bungin, Burhan. 2006. Sosiologi Komunikasi. Jakarta: Kencana.

Croteau, David dan William Hoynes. 1997. Media/Society: Industries, Images, And Audiences. California: Pine Forge Press.

Mulyana, Deddy. 2008. Komunikasi Massa. Bandung: Widya Padjajaran.

2011. Komunikasi Lintas Budaya: Pemikiran, Perjalan dan Khayalan. Bandung: PT. Remaja Rosdakarya. 
Shaw, Alison. 2007. Metode Penelitian Komunikasi: Contoh-Contoh Penelitian Kualitatif Dengan Pendekatan Praktis. Bandung. PT. Remaja Rosdakarya.

Soemandoyo, Priyo. 1999. Wacana Gender \& Layar Televisi: Studi Perempuan dalam Pemberitaan Televisi Swasta. Yogyakarta: LP3y dan Ford Foundation.

Umar, Nasaruddin. 2001. Argumen Kesetaraan Jender Perspektif Al-Qur'an. Jakarta: Paramadina.

\section{Jurnal}

Astuti, Santi Indra. Representasi Perempuan Indonesia dalam Komuniksi Visual: Wacana yang (Belum) Berubah. Jurnal Komunikasi Mediator Volume 5 Nomor 22004.

\section{Internet}

http://id.wikipedia.org/wiki/Feminisme http://www.isi-dps.ac.id/berita/televisi-sebagai-konstruksi-realitas-bagian-i http://psg.uii.ac.id/index.php/RADIO/Amin.html http://www.rahima.or.id/index.php?option=com_content $\& v i e w=\operatorname{article} \& i d=858: b$ agaimana-media-memotret-perempuan- $\&$ catid=1:berita\&Itemid $=18$ http://ekawenats.blogspot.com/2006_03_19_archive.html http ://konvergensi.komunikasi. or. Id / 18 /post /2012 /10 /konvergensi - media dalam - perspektif - feminisme. html 